\section{Increased Rooting of 'Norton' Grape Cuttings Using Auxins and Gibberellin Biosynthesis Inhibitors}

\author{
Kathryn Keeley ${ }^{1}$, John E. Preece ${ }^{2}$, and Bradley H. Taylor ${ }^{3}$ \\ Department of Plant, Soil and GeneralAgriculture, Southern Illinois University, \\ Carbondale, IL 62901-4415
}

Additional index words. cutting storage, grape, hardwood cuttings, propagation, softwood cuttings, Vitis aestivalis

\begin{abstract}
Hardwood and softwood cuttings of Vitis aestivalis Michx. 'Norton' were rooted under intermittent mist in a series of experiments using cuttings collected from two local vineyards. Hardwood cuttings treated in late March responded in a similar manner to KIBA and KNAA. Although there was little increase in the percentage rooting above $22.29 \mathrm{~mm}$ KIBA or $20.72 \mathrm{~mm}$ KNAA $\left(5000 \mathrm{mg} \cdot \mathrm{L}^{-1}\right.$ of either auxin), root number (but not root length) increased linearly on cuttings treated with up to $44.58 \mathrm{~mm}$ KIBA or $41.44 \mathrm{~mm}$ KNAA (10000 $\mathrm{mg} \cdot \mathrm{L}^{-1}$ auxin). Cuttings treated with $10000 \mathrm{mg} \cdot \mathrm{L}^{-1}$ auxin produced up to 4 times more roots than the nontreated controls. The gibberellin biosynthesis inhibitors CCC and PAC had little effect on either hardwood cuttings or softwood cuttings that were harvested, treated and placed in the propagation bench in June. However, when softwood cuttings were collected in August, the most roots were found on cuttings treated with 50.6 mм CCC or $0.85 \mu \mathrm{M}$ PAC. Although all hardwood cuttings were collected at the same time and stored under refrigerated conditions, rooting percentage increased as storage time increased, especially on the nontreated control cuttings. When the cuttings were stored for the longest time (six weeks), KIBA no longer caused more roots per cutting. Chemical names used: potassium salt of indole-3-butyric acid (KIBA), potassium salt of $\alpha$-naphthaleneacetic acid (KNAA), chlormequat chloride (CCC), paclobutrazol (PAC).
\end{abstract}

Vitis aestivalis is a grape species that is native to eastern North America. The cultivar 'Norton' is relatively winter hardy and disease resistant, and in Illinois, acreage planted with this cultivar is increasing (Dami, 2000). This trend will likely continue for the eastern United States as well because of the great quality and aging potential of 'Norton' wine (Morton, 1985). However, because of difficulties with rooting cuttings (Norton and Skirvin, 2001), planting stock is limited and costly.

'Norton' is extremely vigorous vegetatively (Wagner, 1978) and its cuttings root poorly. These two characteristics are typical of plants that produce relatively high levels of gibberellins. Although there are no reports on the hormonal content of 'Norton', there is a general inverse relationship between gibberellin content in cuttings and their ability to form adventitious roots and when gibberellins are applied to cuttings rooting is inhibited (Hansen, 1988). For example, gibberellic acid completely inhibited rooting of $V$. vinifera $\mathrm{L}$. 'Chaush' cuttings (Eris and Celik, 1981). Soaking grape cuttings in water for $24 \mathrm{~h}$ increased rooting from $70 \%$ to $83 \%$ of an easy-to-root clonal rootstock ' $5 \mathrm{BB}$ ' (V.berlandieri Planch. $\mathrm{x}$ V.riparia Michx.) and from $18 \%$ to $38 \%$ for a difficult-to-root clonal rootstock '140 Ruggeri' ( $V$. berlandieri $\times$ V.

Received for publication 5 Dec. 2001. Accepted for publication 25 June 2002. We thank the Illinois CFAR for support of this research.

${ }^{1}$ Former Graduate Student.

${ }^{2}$ Professor, to whom reprint requests should be addressed.

${ }^{3}$ Associate Professor.

HortScience, Vol. 38(2), April 2003 $\mathrm{mm}$ long internodes and 3 to $7 \mathrm{~mm}$ diameter were collected at Mockingbird Farms 26 June 1999 and Owl Creek Vineyards 2 Aug. 1999. All foliage was removed, except the leaf from the most distal node. If the leaf at this node was $>8 \mathrm{~cm}$ long, the terminal half of the leaf was excised.

All cuttings were disinfested by a 5 second immersion in a hydrogen dioxide and peryoxyacetic acid solution (ZeroTol; Biosafe Systems, Glastonbury, Conn.), at the rate of $9.5 \mathrm{~mL}$ of Zerotol per liter of water]. Following immersion in the ZeroTol solution, fresh cuts were made on each end of the hardwood cuttings (leaving all three nodes) and directly below the bottom node for the softwood cuttings. Then, the basal $10 \mathrm{~mm}$ of all cuttings were dipped in treatment solutions (all prepared using deionized water) for $30 \mathrm{~s}$ unless otherwise stated. The bottom two nodes of cuttings were placed within the medium, leaving only the top node uncovered.

Hardwood cuttings were rooted in a moist 1 vermiculite : 1 perlite (by volume) medium in plastic Rootrainers (Hummert Intl., Earth City, Mo.) each with a cell volume of $90 \mathrm{~cm}^{3}$. Softwood cuttings were rooted in the same medium in standard $10-\mathrm{cm}$ pots.

Environmental. Hardwood cuttings were rooted on a greenhouse bench with bottom heat at $30^{\circ} \mathrm{C}$ and mist set on a timer at $6 \mathrm{~s}$ every 6 min for 13 daylight hours per day and with air temperature maintained at $21^{\circ} \mathrm{C}$. Because of the hot summer conditions, no supplemental bottom heat was used for the softwood cuttings, which were also placed under intermittent mist at 3 s every 3 min with an air temperature of $30{ }^{\circ} \mathrm{C}$ day/24 ${ }^{\circ} \mathrm{C}$ night. Cuttings were drenched with etridiazole and thiophanatemethyl (7.5 g Banrot $40 \%$ of WP per liter of water) for control of fungal pathogens if there was any sign of browning of the roots or stems during the rooting process.

Hardwood cuttings treated with KIBA and KNAA. After $28 \mathrm{~d}$ of cold storage, on 26 Mar. 1999, hardwood cuttings were treated with 0 , $11.145,22.29,33.435$, or $44.58 \mathrm{~mm} \operatorname{KIBA}(0$, $2500,5000,7500$, or $10000 \mathrm{mg}$ of KIBAper liter of water); $0,10.36,20.72,31.08$, or $41.44 \mathrm{~mm}$ KNAA $(0,2500,5000,7500$ or $10000 \mathrm{mg}$ of KNAA per liter of water); or a combination of $11.124+10.36,11.124+20.72,22.29+10.36$, or $22.29+20.72 \mathrm{~mm} \mathrm{KIBA}+$ KNAA.

Timing of KIBA soaks on hardwood cuttings. After $41 \mathrm{~d}$ of cold storage, on $7 \mathrm{Apr}$. 1999, hardwood cuttings were treated with 0 , $1.115,2.229,11.145$, or $22.29 \mathrm{~mm}$ KIBA for either $30 \mathrm{~s}$, or $24 \mathrm{~h}$.This resulted in a $5 \times 2$ factorial combination of auxin concentrations and duration of treatments.

Hardwood cuttings treated with gibber-

Plant materials. Dormant, three node, $20 \pm$ $3 \mathrm{~cm}$ long hardwood cuttings with $15-100 \mathrm{~mm}$ long internodes and 3-7 mm diameter of Vitis aestivalis 'Norton' were taken from 3-year-old vines at Mockingbird Farms, Makanda, Ill. and 8-year old vines at Owl Creek Vineyards, Cobden, Ill., on 26 and 27 Feb. 1999. The cuttings were stored in closed 125-L, 0.02-mm-thick black polyethylene garbage bags with two damp paper towels at $5{ }^{\circ} \mathrm{C}$ until used. Actively growing $15 \pm 2 \mathrm{~cm}$ long softwood cuttings with $15-60$ ellin biosynthesis inhibitors: CCC, PAC, and the auxin KIBA. After $48 \mathrm{~d}$ of cold storage, on 14 Apr. 1999, hardwood cuttings were treated $0,3.16,6.33,12.65,25.3$, or $50.6 \mathrm{~mm} \mathrm{CCC}(0$, $500,1000,2000,4000$, or $8000 \mathrm{mg}$ CCC per liter of water) or $0,1.7,3.4,6.8,13.6$, or 27.2 $\mu \mathrm{M} \mathrm{PAC}(0,0.5,1.0,2.0,4.0$, or $8.0 \mathrm{mg}$ of PAC per liter of water). Half of the cuttings in each treatment were treated with 22.29 mM KIBAand the other half received no auxin treatment. 
Softwood cuttings treated with gibberellin biosynthesis inhibitors: CCC, PAC, and the auxin KIBA. On 26 June 1999, softwood cuttings were collected at Mockingbird Farms, and on 2 Aug. 1999, cuttings were collected from Owl Creek Vineyards. Cuttings were treated $0,1.58,3.16,6.33,12.65,25.3$, or $50.6 \mathrm{~mm}$ CCC or $0,0.85,1.7,3.4,6.8,13.6$, or $27.2 \mu \mathrm{M}$ PAC. Half of the cuttings in each treatment were treated with $4.458 \mathrm{~mm}$ KIBA (1000 mg of KIBA per liter of water) and the other half received no auxin treatment.

Experimental design and statistical analysis. In each experiment, cuttings were arranged in a randomized complete-block design with 10 blocks per run and one cutting per treatment per block, with blocking according to cutting diameter and internode length. Each experiment was conducted concurrently from the mature vines at Owl Creek Vineyards for one run and cuttings from the recently established vines at Mockingbird Farms for the other run. Data were collected on root number per cutting, root length and percentage rooting within treatment and analyzed using the general linear model procedures (SAS Inst., 1996) to generate analysis of variance (ANOVA). Runs were tested for homogeneity and were separated if heterogeneous. Main effects and interactions for a fixed effects model were tested using pooled run and block(run) interactions. Where appropriate, data were transformed using the $(y+0.5)^{0.5}$ or $\log (y+1.0)$ to normalize data (Steel and Torrie, 1980). Level of significance, contrasts where appropriate and $t$ tests for paired comparisons are presented in tables and figure legends.

\section{Results}

Hardwood cuttings treated with KIBA and $K N A A$. Because the cuttings responded in a
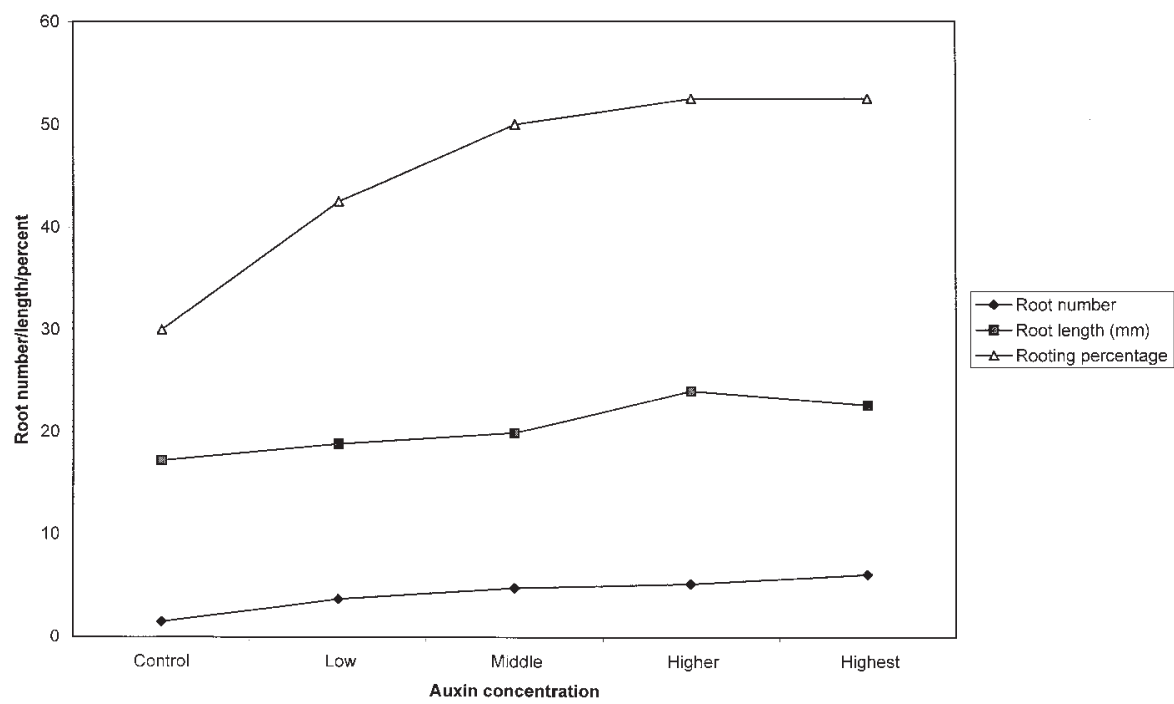

Fig. 1. The effect of auxin concentration on mean root number, mean root length, and percent rooting of hardwood cuttings of 'Norton' grape planted 26 Mar. 1999. For statistical analysis, root number, and root length data were transformed using the $(y+0.5)^{0.5}$ transformation, nontransformed means are presented. The number of roots per cutting was significant at the $1 \%$ level according to the $\mathrm{F}$ test with 4 and $171 \mathrm{df}$. According to a single degree of freedom contrast, the effect of increasing concentration of auxin was significantly linear at the $1 \%$ level according to $\mathrm{F}$ test with 1 and $171 \mathrm{df}$. The 5\% and $1 \% t$ test values for root number are 2.5 and 3.3, respectively. The root length and rooting percentage data were not significant. Each mean is based on 40 cuttings averaged across KIBA and KNAA. The auxin concentrations, control, low, middle, higher, and highest represent $0,2500,5000,7500$, and $10000 \mathrm{mg} \cdot \mathrm{L}^{-1}$ auxin, which are equivalent to 0 , $11.145,22.29,33.435$, or 44.58 mм KIBA and $0,10.36,20.72,31.08$, or 41.44 mм KNAA. to 7 roots per cutting with a root length of 13 to $22 \mathrm{~mm}$ (Table 1). The effects of auxin and gibberellin biosynthesis inhibitors on root number and root length varied with concentration.

For the cuttings taken in August, there was a significant interaction between gibberellin biosynthesis inhibitors and concentration for both root number and length. Highest root numbers were on cuttings treated with $50.6 \mathrm{~mm} \mathrm{CCC}$ or $0.85 \mu \mathrm{M}$ PAC (Fig. 2). Cuttings with either of these treatments produced more than double the number of roots compared to the control cuttings. This indicates that PAC is thousands of times more active than CCC for stimulating root initiation in softwood 'Norton' grapevine cuttings, especially when taken at a less optimal time (August) for softwood cuttings.

Timing. With the hardwood cutting experiments, the control cuttings rooted better with each successive experiment. Although the experiments were not originally designed to be compared over time, there were two treatments that each had in common: the control and 22.29 mm KIBA. A significant $(P<0.05)$ difference was noted for root number as duration of cold storage of cuttings increased (Table 2). Cuttings

Table 1.Effect of growth retardant, concentration and KIBA on mean root number, mean root length, and percent rooting of softwood 'Norton' grape cuttings ${ }^{2}$ taken in June 1999.

\begin{tabular}{|c|c|c|c|c|}
\hline $\begin{array}{l}\text { Retardant } \\
\text { concentration }\end{array}$ & $\begin{array}{l}\text { KIBA } \\
(\mathrm{mm})^{y}\end{array}$ & $\begin{array}{c}\text { Root } \\
\text { no. }\end{array}$ & $\begin{array}{l}\text { Root } \\
\text { length } \\
(\mathrm{mm})\end{array}$ & $\begin{array}{l}\text { Rooting } \\
(\%)\end{array}$ \\
\hline \multicolumn{5}{|c|}{ CCC } \\
\hline \multirow[t]{2}{*}{0} & 0 & 5.0 & 13.1 & 90 \\
\hline & 4.458 & 8.8 & 24.2 & 90 \\
\hline \multirow[t]{2}{*}{1.58} & 0 & 8.3 & 23.0 & 100 \\
\hline & 4.458 & 5.1 & 19.0 & 90 \\
\hline \multirow[t]{2}{*}{3.16} & 0 & 5.4 & 30.6 & 90 \\
\hline & 4.458 & 4.8 & 11.0 & 80 \\
\hline \multirow[t]{2}{*}{6.33} & 0 & 6.7 & 15.7 & 90 \\
\hline & 4.458 & 3.4 & 7.5 & 70 \\
\hline \multirow[t]{2}{*}{12.65} & 0 & 5.2 & 18.2 & 90 \\
\hline & 4.458 & 4.5 & 18.7 & 90 \\
\hline \multirow{2}{*}{25.30} & 0 & 7.4 & 19.7 & 80 \\
\hline & 4.458 & 4.8 & 15.2 & 80 \\
\hline \multirow[t]{2}{*}{50.60} & 0 & 4.3 & 19.2 & 80 \\
\hline & 4.458 & 6.8 & 20.8 & 90 \\
\hline \multicolumn{5}{|c|}{$P A C(\mu M)$} \\
\hline \multirow[t]{2}{*}{0} & 0 & 6.8 & 21.8 & 90 \\
\hline & 4.458 & 6.9 & 19.4 & 90 \\
\hline \multirow[t]{2}{*}{0.85} & 0 & 7.1 & 15.8 & 90 \\
\hline & 4.458 & 4.7 & 20.0 & 90 \\
\hline \multirow[t]{2}{*}{1.7} & 0 & 4.8 & 16.4 & 90 \\
\hline & 4.458 & 8.1 & 14.4 & 80 \\
\hline \multirow[t]{2}{*}{3.4} & 0 & 4.3 & 13.2 & 80 \\
\hline & 4.458 & 7.7 & 17.9 & 80 \\
\hline \multirow[t]{2}{*}{6.8} & 0 & 5.0 & 13.3 & 70 \\
\hline & 4.458 & 5.2 & 15.4 & 70 \\
\hline \multirow[t]{2}{*}{13.6} & 0 & 3.3 & 7.3 & 80 \\
\hline & 4.458 & 7.5 & 26.5 & 90 \\
\hline \multirow[t]{2}{*}{27.2} & 0 & 7.4 & 28.7 & 100 \\
\hline & 4.458 & 5.1 & 15.2 & 90 \\
\hline
\end{tabular}

Significance $5 \% t$ test $^{\mathrm{x}}$ $3.8 \quad 13.8$

${ }^{2}$ These calculations are based on the mean of 10 cuttings from Mockingbird Farms.

${ }^{y}$ For statistical analysis, data were transformed using the $\log (y+1.0)$ transformation. Nontransformed means are presented.

${ }^{\mathrm{x}} t$ test for paired comparisons.

"Significant at the 5\% level according to $F$ test with 6 and $243 \mathrm{df}$

HortScience, Vol. 38(2), April 2003 


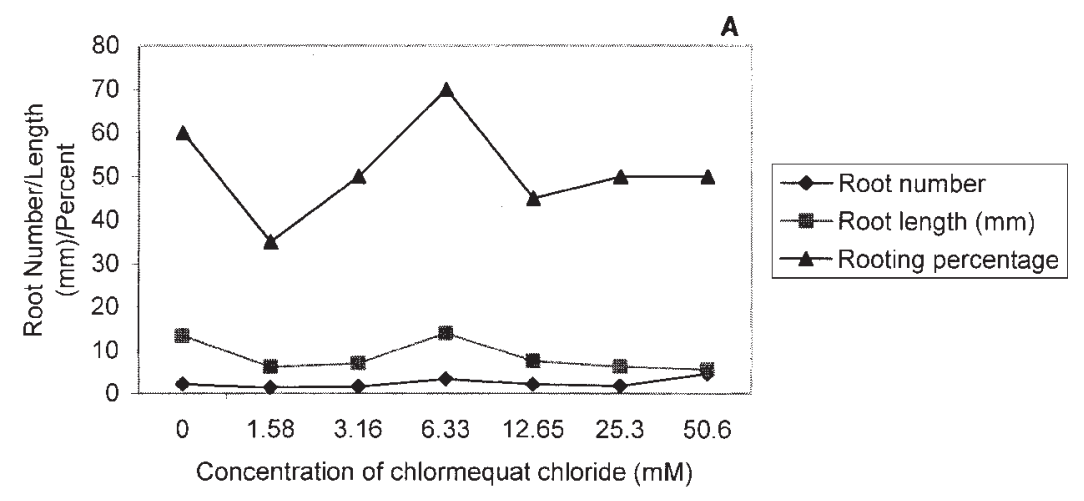

B

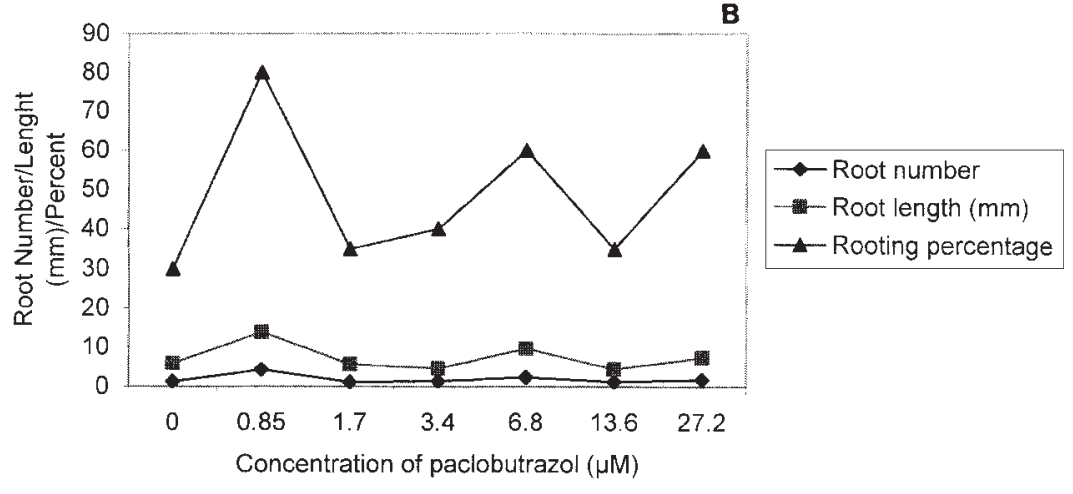

Fig. 2. The effect of (A) chlormequat chloride (CCC) and (B) paclobutrazol (PAC) concentrations on mean root number, mean root length and percent rooting of softwood 'Norton' grape cuttings taken in Aug.1999. For statistical analysis, root number and root length data were transformed using the log $(y+1.0)$ transformation, nontransformed means are presented. Root number was significant at the $1 \%$ level, and root length was significant at the 5\% level according to F test with 6 and $243 \mathrm{df}$. The 5\% and $1 \% t$ test values for root number are 2.1 and 2.7 and for root length are 7.0 and 9.3 , respectively. The percentage data were not significant. Each mean is based on 20 cuttings averaged across two auxin concentrations.

Table 2. Effect of date 'Norton' grape cuttings were prepared, treated, and placed under intermittent mist on mean root number, mean root length, and percent rooting ${ }^{\mathrm{z}}$ of hardwood cuttings.

\begin{tabular}{|c|c|c|c|c|c|c|c|}
\hline \multirow[b]{2}{*}{$\begin{array}{l}\text { Experiment } \\
\text { date }\end{array}$} & \multirow[b]{2}{*}{$\begin{array}{l}\text { Days in } \\
\text { storage }\end{array}$} & \multicolumn{2}{|c|}{ Root no. } & \multicolumn{2}{|c|}{ Root length } & \multicolumn{2}{|c|}{ Rooting (\%) } \\
\hline & & $\begin{array}{c}\text { KIBA } \\
0\end{array}$ & $\begin{array}{c}\mathrm{mM} \\
22.29\end{array}$ & $\begin{array}{c}\text { KIBA } \\
0\end{array}$ & $\begin{array}{c}\mathrm{mM} \\
22.29\end{array}$ & $\begin{array}{c}\text { KIBA } \\
0\end{array}$ & $\begin{array}{c}\mathrm{mM} \\
22.29\end{array}$ \\
\hline 26 Mar. 1999 & $(28)$ & 0.9 & 5.5 & 18.9 & 23.5 & 30 & 55 \\
\hline 7 Apr. 1999 & (41) & 2.0 & 5.5 & 14.9 & 20.1 & 65 & 55 \\
\hline 14 Apr. 1999 & (48) & 1.7 & 1.4 & 24.0 & 19.0 & 77.5 & 72.5 \\
\hline $\begin{array}{l}\text { Significance } \\
5 \% t \text { test }^{\mathrm{y}}\end{array}$ & & \multicolumn{2}{|c|}{$*$} & \multicolumn{2}{|c|}{ NS } & \multicolumn{2}{|c|}{ NS } \\
\hline
\end{tabular}

${ }^{2}$ Calculations based on mean of 20 cuttings ( $28 \mathrm{~d}$ and $41 \mathrm{~d}$ ) and 40 cuttings ( $\left.48 \mathrm{~d}\right)$.

${ }^{y} t$ test for paired comparison.

Ns, "Nonsignificant or significant at the 5\% level or nonsignificant according to $\mathrm{F}$ test with 2 and 133

that were in cold storage for short amounts of time produced significantly more roots when treated with KIBA than when not treated with auxin. As time in cold storage increased to 48 $\mathrm{d}$, the addition of KIBA had no effect. There was no significant effect of storage time on root length or rooting percentage.

\section{Discussion}

Rooting was improved during early spring with application of auxin to 'Norton' hardwood cuttings. This effect was on hardwood cuttings that had been in cold storage for only $28 \mathrm{~d}$. However, hard-to-root grapevines are frequently subjected to cold storage, pre-callusing, and application of plant growth regulators to enhance rooting (Warmund et al., 1986). According to Alley (1979), applications of IBA treatments on hard-to-root rootstock cuttings such as Vitis champini 'Salt Creek' and 'Dog Ridge' improved overall rooting.

We noted a greater effect of the gibberellin biosynthesis inhibitors on root number and length on softwood cuttings than on hardwood cuttings. However, results for initiating rooting with the application of gibberellin biosynthesis inhibitors were inconsistent, especially when the softwood cuttings were placed in the mist bench at the optimum time (June). Gibberellin biosynthesis inhibitors were most useful in rooting softwood cuttings taken at a suboptimal time for rooting (August). Various gibberellin biosynthesis inhibitors have been shown to promote rooting (Davis and Sankhla, 1988), and when CCC was applied to V. vinifera 'Chaush' cuttings, it increased the root fresh weight (Eris and Celik, 1981).

Long-term cold storage (minimum of $40 \mathrm{~d}$ ) may increase rooting of grape hardwood cuttings. Southeastern Missouri commercial wine grape propagators indicated that cuttings placed into a rooting medium during late spring tended to root better than cuttings placed in the medium earlier that same year (personal communication), which agrees with our findings on hardwood cuttings. Further research on time of propagation and length of hardwood cutting storage is needed to improve the horticultural application of our results.

It has been noted that 'Norton' is vegetatively vigorous (Wagner, 1978) and the most undesirable characteristic of 'Norton' vines to propagators is the poor rooting of cuttings (Tarara and Hellman, 1991). Generally, easyto-root grapevines are propagated by dormant hardwood cuttings without the use of special rooting techniques. 'Norton' hardwood cuttings can be rooted at a high percentage with applications of auxin and/or cold storage prior to rooting. Softwood cuttings will root in a high percentage if they are taken during the early summer when the vines are actively growing.

\section{Literature Cited}

Alley, C.J. 1979. Grapevine propagation/ VI. Rooting of cuttings: effects of indolebutyric acid(IBA) and refrigeration on rooting. Amer. J. Enol. \& Viticult. 30(1):28-32.

Bartolini, G., M.A. Toponi, and L. Santini. 1986. Endogenous GA-like substances in dipping waters of cuttings of two Vitis rootstocks. Amer. J. Enol. \& Viticult. 37:1-6.

Dami, I. 2000. 1999 grape growers and vintners survey, p. 1-8. In: Proc. Illinois Grape Growers and Vintners Assn. Annu. Conf, Springfield, Ill.

Davis, T.D. and N. Sankhla. 1988. Effect of shoot growth retardants and inhibitors on adventitious rooting, p. 174-184. In: T.D. Davis, B.E. Haissig, and N. Sankhla (eds.). Adventitious root formation in cuttings. Dioscorides Press, Portland, Ore.

Eris, A. and H. Celik. 1981. Effects of some plant growth regulators on bud burst and rooting of Vitis vinifera L. cv. Chaush cuttings. Amer. J. Enol. Viticult. 22:122-124.

Hansen, J. 1988. Influence of gibberellins on adventitious root formation, p. 162-173. In: T.D. Davis, B.E. Haissig, and N. Sankhla (eds.). Adventitious root formation in cuttings. Dioscorides Press, Portland, Ore.

Kracke, H., G. Cristoferi, and B. Marangoni. 1981. Hormonal changes during the rooting of hardwood cuttings of grapevine rootstocks. Amer. J. Enol. \& Viticult. 32:135-137.

Morton, L.T. 1985. Winegrowing in Eastern America. Cornell Univ. Press, Ithaca, N.Y.

Norton, M.A. and R.M. Skirvin. 2001. Micropropagation of 'Norton' winegrape. HortTechnology 11: 206-208.

SAS Institute. 1996. The SAS system. Release 6.12. SAS Inst., Cary, N.C.

Steel, R.G.D. and J.H. Torrie. 1980. Principles and procedures of statistics a biometrical approach, $2^{\text {nd }}$ ed. McGraw-Hill, New York.

Tarara, J.M., and E.W. Hellman. 1991. Norton and Cynthiana premium native wine grapes. Fruit Var. J. 45(2):66-69.

Wagner, P.M. 1978. A wine-growers guide. Revised ed. Alfred A. Knopf, New York.

Warmund, M.R.,C.J. Starbuck, and LLockshin. 1986. Growth, cold hardiness, and carbohydrate content of Vidal blanc grapevines propagated by hardwood and softwood cuttings. Amer. J. Enol. \& Viticult. 37(3):215-219. 